\title{
Energy Balance Study of Combined Carbonization and Liquefaction of Coconut Shell
}

\author{
Joshi Priyanka Suhas $^{1 *}$, Khot Samreen Anwarali ${ }^{1}$, A.G. Mohod ${ }^{2}$ and Y.P. Khandetod ${ }^{2}$ \\ ${ }^{1}$ Department of Agri. Engg., ${ }^{2}$ Department of Electrical and Other Energy Sources, College of \\ Agricultural Engineering and Technology, Dr. BSKKV, Dapoli, \\ Ratnagiri - 415 712, Maharashtra, India \\ *Corresponding author
}

\section{A B S T R A C T}

The work was carried out to study the combine carbonization and liquefaction of coconut shell (Cocus nucifera) biomass in order to produce the charcoal and bio crude oil. The characterization was carried out before and after carbonization process in terms of

\section{Keywords}

Energy, Balance, Carbonization,

Liquefaction,

Coconut shell

Article Info

Accepted:

16 August 2018

Available Online:

10 September 2018 proximate analysis, higher calorific value and bulk density. The carbonization cum liquefaction was evaluated in terms of mass conversion efficiency, volumetric energy ratio, energy density ratio and properties of charcoal and bio-oil. The results obtained from the characterization of selected coconut shell (Cocus nucifera) biomass revealed that coconut shell showed its higher suitability for carbonization cum liquefaction with higher fixed carbon $(21.796 \%)$, lower ash $(1.84 \%)$, higher calorific value $(5041 \mathrm{kcal} / \mathrm{kg})$ and high bulk density $\left(486.33 \mathrm{~kg} / \mathrm{m}^{3}\right)$. Total amount of charcoal produced by carbonization cum liquefaction process from $32.948 \mathrm{~kg}$ coconut shell was $10.83 \mathrm{~kg}$, with $3140 \mathrm{ml}$ bio-oil, the fixed carbon content of coconut shell charcoal was $76.497 \%$. The higher calorific value of coconut shell charcoal and bio-oil was $6795 \mathrm{kcal} / \mathrm{kg}$ and $5320 \mathrm{kcal} / \mathrm{kg}$, respectively. The mass conversion efficiency, volumetric energy ratio and energy density ratio of charcoal and bio-oil production using coconut shell (Cocus nucifera) was found to be 42.4 per cent, 4.04 per cent and 2.51 per cent respectively. Coconut shell fuel showed its higher suitability for combine charcoal and bio-oil production in terms of mass conversion efficiency, volumetric energy ratio and energy density ratio.

\section{Introduction}

Coconut (Cocus nucifera) is a popular plantation and is grown in 92 countries worldwide. India accounts for $23.34 \%$ of the world's coconut production, producing $10,894,000$ tonnes annually (FAO, 2009). The Konkan region of Maharashtra is a major coconut producing region in the Maharashtra. The average production of coconuts in the
Konkan region is about 1,313.9 lakh nuts annually (Anonymous, 2010).

An individual coconut fruit is made of an outer exocarp, a thick fibrous fruit coat known as husk, the hard protective endocarp or shell called "eyes" are at one end of the nut.". The coconut shell is the strongest part covered in coconut fruit. Inside the shell there is a thin, white, fleshy layer, about $12.25 \mathrm{~mm}$ thick at 
maturity, known as the "coconut meat". The interior of the nut is hollow and is partially filled 999with watery liquid called "coconut milk. The coconut shell accounts about 135 $\mathrm{g} / \mathrm{nut}$ and is used as biomass for heat generation. The average production potential of coconut shell as a biomass in Konkan region is $17,737.65$ tonnes annually (Anonymous 2010). Conventionally, the coconut shell is subjected to open burning or burnt in boilers, which contribute significantly to $\mathrm{CO}_{2}$ and methane emission.

Carbonization is more convenient process to produce charcoal which is the energy dense, smoke free fuel and consist of the fixed carbon content about $70 \%$ or more. In carbonization process, large amount of heat is liberated in atmosphere in the form of flue gases and efficiency of carbonization as separate process is reduced. Solid biomass properties can be improved by carbonization, but converting them to liquid may further expand their utilization. Liquid bio fuels are easier to store, transport and handle than solid biomass. Pyrolysis is promising process to produce liquid fuels from biomass. The bio-oil is immiscible in fossil fuels and it has a heating value of about half of what a conventional fuel oil has.

If the flue gases from carbonization process are allowed to condense, then along with charcoal, bio-oil is also produced which may increase total efficiency of process and also flue gases escapes at low temperature after liquefaction in atmosphere reduces the hazard to environment. The combine effect of carbonization and liquefaction of the biomass was studied with following specific objectives

\section{Objectives}

To evaluate the performance of carbonization and liquefaction unit using coconut shell as a feed stock.
To study energy balance of the carbonization and liquefaction process of coconut shell.

\section{Materials and Methods}

The carbonization and liquefaction of the coconut shell was carried out to produce the charcoal and bio-oil simultaneously using the slow pyrolysis process. The coconut shell was carbonized in the charcoal kiln and the exit gases were condensed using cold water as a heat exchanging medium. The carbonization cum liquefaction unit was evaluated at $17^{\circ} 45^{\prime}$ $\mathrm{N}$ latitude and $73^{\circ} 26^{\prime} \mathrm{E}$ longitude and at an altitude of $256 \mathrm{~m}$ above mean sea level. The stepwise methodology to accomplish the objectives is summarized under the following sub headings.

Characterization of coconut shell before and after carbonization.

Performance evaluation of biomass carbonization cum liquefaction unit.

Characterization of bio-oil

Study the mass and energy balance of carbonization and liquefaction process.

\section{Carbonization cum liquefaction unit}

The technical specification of carbonization cum liquefaction unit is shown in Table 1 . The schematic view of liquefaction unit is depicted in Figure 1. The carbonization cum liquefaction unit consist of carbonization kiln, double jacketed condensing unit, inlet and outlet for cooling water, inlet and outlet for flue gases, collecting port for bio-oil.

Double jacketed condensing unit

The size of double jacketed condensing unit was determined by considering the amount of flue gases generated during the carbonization 
process. The condensing unit was developed for condensation of hot flue gases into bio-oil. The inner and outer jacket has been $30 \mathrm{~mm}$ apart each other to hold the water outside and flue gases inside.

\section{Inlet and outlet for cooling water}

The inlet and outlet pipe for cooling water and hot water was provided on the outer side of jacket. It helped to supply the heat exchanging medium for transferring the heat from hot flue gases to water.

\section{Inlet and outlet for flue gases}

The inlet and outlet pipes were provided on the inner jacket to transfer hot flue gases generated from carbonization process to the atmosphere.

\section{Collecting port for bio-oil}

The bio-oil collecting port of the unit was connected to the inner jacket with tapered shape. The tapered shape provided the free flow facility to the oil into collecting jar.

Characterization of coconut shell and its output after carbonization and liquefaction

The coconut shell (Cocus nucifera) was used as feedstock for evaluation of carbonization cum liquefaction unit. The material was characterized before and after carbonization in terms of proximate analysis, calorific value and bulk density.

The moisture content of coconut shell and its charcoal was determined by oven dry method as per ASTMD-3713. The volatile matter of coconut shell and its charcoal was determined by using muffle furnace as per ASTMD-3175. The ash content of coconut shell and its charcoal was determined by using muffle furnace as per ASTMD-3174. The fixed carbon content was calculated by using the weight difference method as Fixed carbon (\%) $=100-\%$ (moisture content + volatile matter + ash content).

The higher heating value of material was determined by using bomb calorimeter. The higher calorific value of solid fuel using bomb calorimeter experiment was determined as;

Calorific value $(\mathrm{kcal} / \mathrm{kg})$

$$
=\frac{(W+w) \times\left(T_{2}-T_{1}\right)}{x}
$$

Where,

$\mathrm{W}=$ Mass of water placed in calorimeter, $\mathrm{g}$

$\mathrm{W}=$ Water equivalent of apparatus, $\mathrm{g}$

$\mathrm{T}_{1}=$ Initial temperature of water in calorimeter, ${ }^{\circ} \mathrm{C}$

$\mathrm{T}_{2}=$ Final temperature of water in calorimeter, ${ }^{\circ} \mathrm{C}$

$X=$ Mass of fuel sample taken in the crucible, $\mathrm{g}$

The bulk density of selected material was measured using a known volume cylindrical shaped container of 200 lit. $\left(0.2 \mathrm{~m}^{3}\right)$.The $\mathrm{pH}$ of bio oil was measured using $\mathrm{pH}$ meter to determine the nature of crude oil. The higher heating value of bio oil was determined by using bomb calorimeter. The viscosity of biooil was measured by using redwood viscometer and reported in terms of centi stocks.

\section{Performance evaluation of carbonization cum liquefaction unit}

The performance evaluation of biomass carbonization cum liquefaction unit was carried out to study mass conversion of fuel, energy density ratio and volumetric energy 
ratio of process by conducting three test of coconut shell as a biomass. The following parameters were measured during the performance evaluation of carbonization cum liquefaction unit and average values were reported as result.

Weight of sample $(\mathrm{kg})$ : The quantity of selected biomass material for carbonization cum liquefaction unit process was measured by using weighing balance.

Size and density $\left(\mathrm{kg} / \mathrm{m}^{3}\right)$ : The size and density of material was measured before and after carbonization cum liquefaction process.

Average wind speed $(\mathrm{m} / \mathrm{s})$ : Wind speed was measured with the help of digital anemometer during experimentation.

Starting and operating time (minute): The time after pre-ignition of carbonization chamber known is as starting period. Time span after pre-ignition of carbonization chamber to completion of carbonization process known is as operating period was measured with help of stop watch.

Quantity of supplementary fuel (ml): The supplementary fuel was needed for preignition of biomass in carbonization chamber. The quantity of supplementary fuel used for every test was measured and recorded.

Temperature of flue gases at exit of carbonization kiln and liquefaction unit: The temperature of flue gases which liberated are from exit of carbonization kiln as well as exit of liquefaction unit was measured by using Ktype thermometer at an interval of 30 minutes.

Temperature of inlet and outlet of cooling water: The temperature of inlet cooling and outlet hot water from condensing unit was measured by using glass thermometer at an interval of 30 minutes.
Output of carbonization $(\mathrm{kg})$ : The output material obtained after carbonization process included charcoal, ash and unburnt materials. After every test run, the output material weighed and noted down (Plate 2).

Output of liquefaction (kg): The output obtained after liquefaction process bio-oil, after every test run, was measured and noted down (Plate 3).

The mass and energy balance of carbonization process based on the average results were studied. The performance evaluation of carbonization and liquefaction process was determined in terms of mass conversion efficiency, volumetric density ratio and energy density ratio.

The mass conversion efficiency is the ratio in terms of mass output after carbonization and liquefaction process to mass input before carbonization in kiln.

Mass conversion efficiency $(\%)=$ $\underline{\text { Output after carbonization+0utput after liquefaction }} \times$

Mass of input 100

The volumetric energy ratio is the ratio of volumetric energy of charcoal and bio-oil produced after carbonization and liquefaction to volumetric energy of biomass before carbonization.

Volumetric energy ratio= Volumetric energy of coal+Volunetric energy of bio-oil

Volumetric energy of biomass

The energy density is the ratio of energy of carbonization and liquefaction and hot water to energy of biomass.

Energy density
Carbonization output energy +Liquefaction energy +Energy in Hot water Bnergy in biomass 


\section{Results and Discussion}

Characterization of selected biomass and its output before and after carbonization and liquefaction

The characterizations of coconut shell (Cocus nucifera) and its output were carried out as per standard test procedures. The results obtained are summarized in Table 2. It was observed that, the moisture content of coconut shell was decreased from 12.38 per cent to 6.50 per cent during carbonization process. The volatile matter of coconut shell after carbonization was decreased from 64 per cent to 13 per cent. The fixed carbon content of coconut shell was increased from 22 per cent to 77 per cent and calorific value was increased from 5041 $\mathrm{kcal} / \mathrm{kg}$ to $6795 \mathrm{kcal} / \mathrm{kg}$ after carbonization. The calorific value of bio-oil was found to be $5320 \mathrm{kcal} / \mathrm{kg}$. The $\mathrm{pH}$ of bio-oil was found to be 5.25 which shows acidic nature due to presence of pyrogalic acid.

\section{Performance evaluation of carbonization cum liquefaction unit}

The results obtained from the evaluation of carbonization cum liquefaction unit are summarized in Table 3.
It was observed that, total operating time required for carbonization of coconut shell (Cocus nucifera) biomass was $7.16 \mathrm{hr}$. About $30-40 \mathrm{~kg}$ of biomass was carbonized within $7.16 \mathrm{hrs}$. in carbonization and liquefaction unit. The carbonization and liquefaction of coconut shell (Cocus nucifera) biomass revealed that, the final output was $10.83 \mathrm{~kg}$ charcoal(32.86\%), $1.64 \mathrm{~kg}$ unburnt $(4.977 \%)$, $0.283 \mathrm{~kg}$ of ash $(0.86 \%)$ and bio-oil $3140 \mathrm{ml}$.

\section{Thermal profile of carbonization and liquefaction}

The variation in temperature of exit flue gases from carbonization kiln, liquefaction unit with corresponding ambient temperature is depicted in Figure 2.

It was observed that, the temperature of flue gases at exit of carbonization varied in the range of 220 to $250^{\circ} \mathrm{C}$ which is hazardous for environment, while the temperature of flue gases at the exit of liquefaction varied in the range of 40 to $55{ }^{0} \mathrm{C}$ which is safe for the environment.

This shows that condensing flue gases at exit of carbonization reduces temperature of flue gases which is beneficial for environment (Fig. 3 and 4).

Fig.1 Schematic view of carbonization cum liquefaction unit

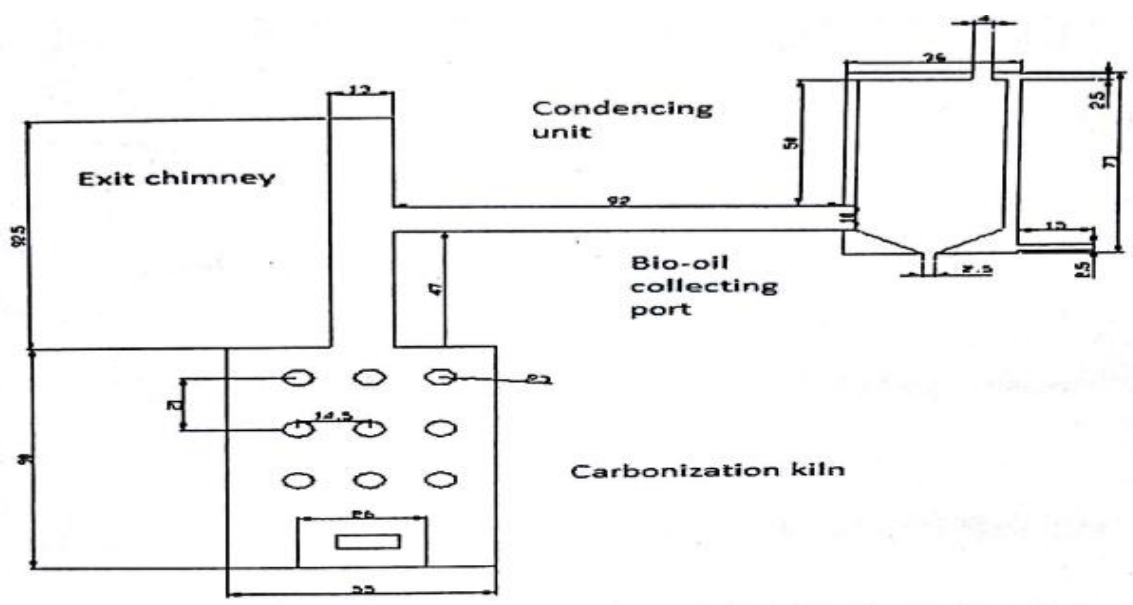


Fig.2 Thermal profile of exit flue gases from carbonization cum liquefaction unit

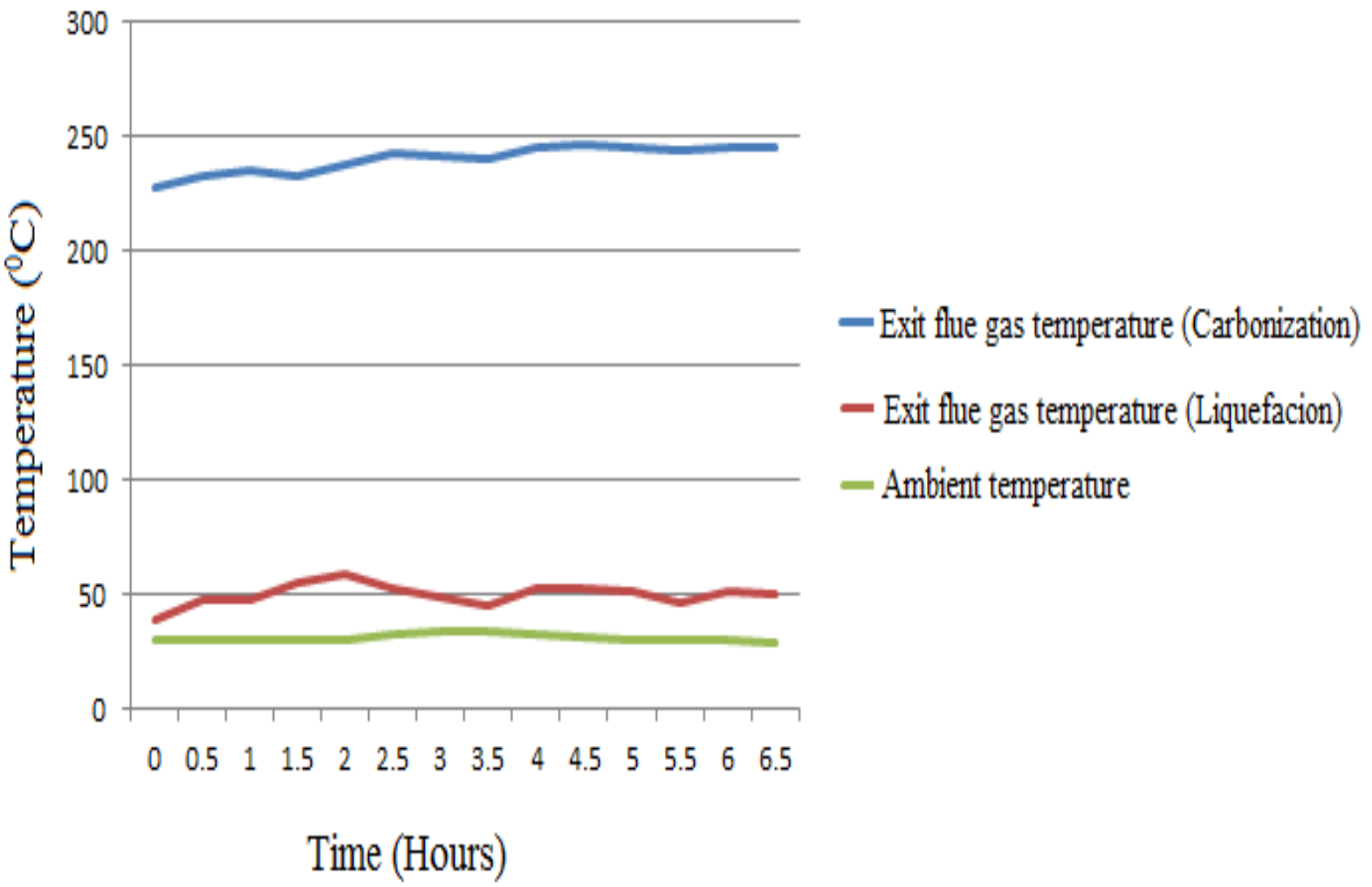

Fig.3 Pictorial view of output after Carbonization from coconut shell

Fig.4 Pictorial view of output after Liquefaction from coconut shell
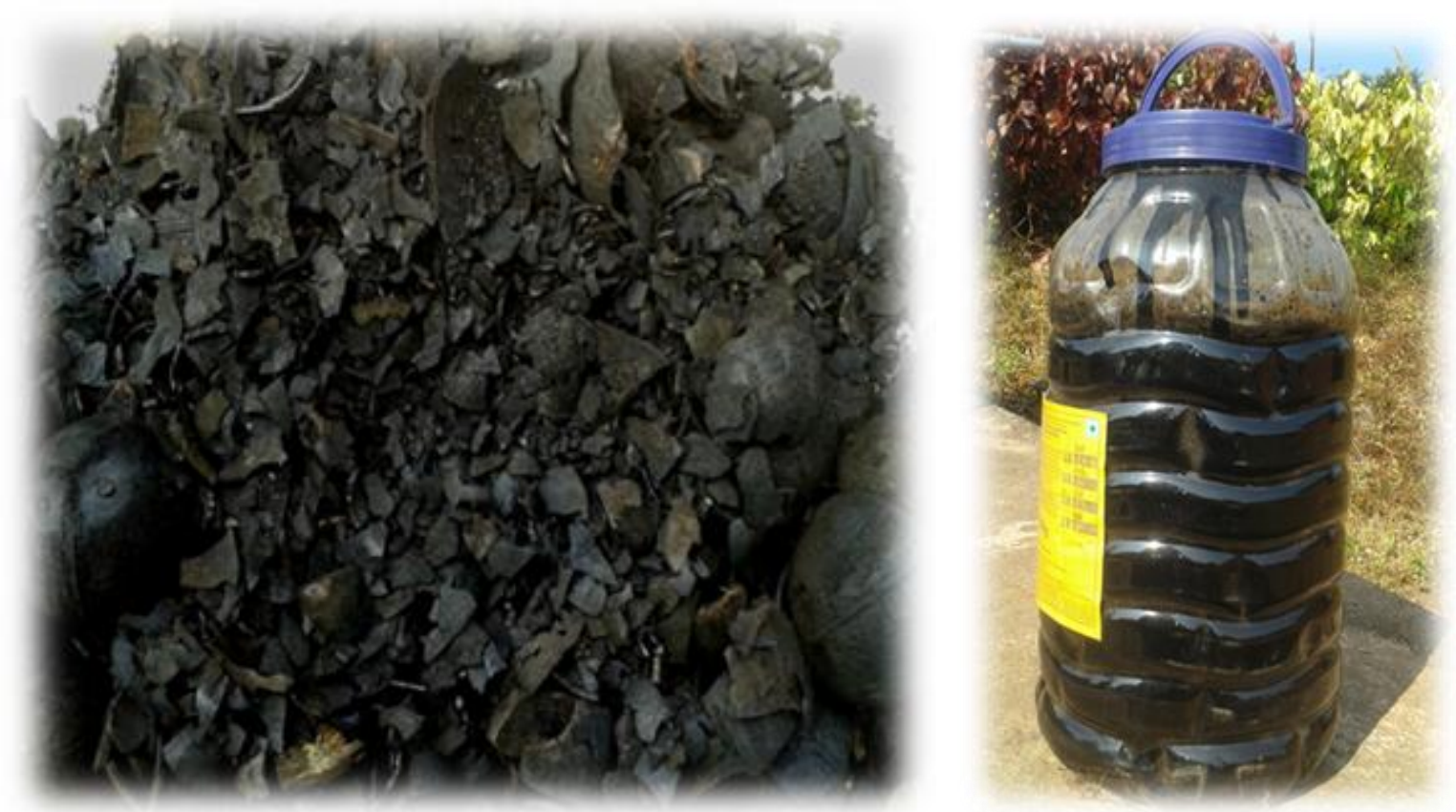
Plate.1 Pictorial view of carbonization cum liquefaction unit

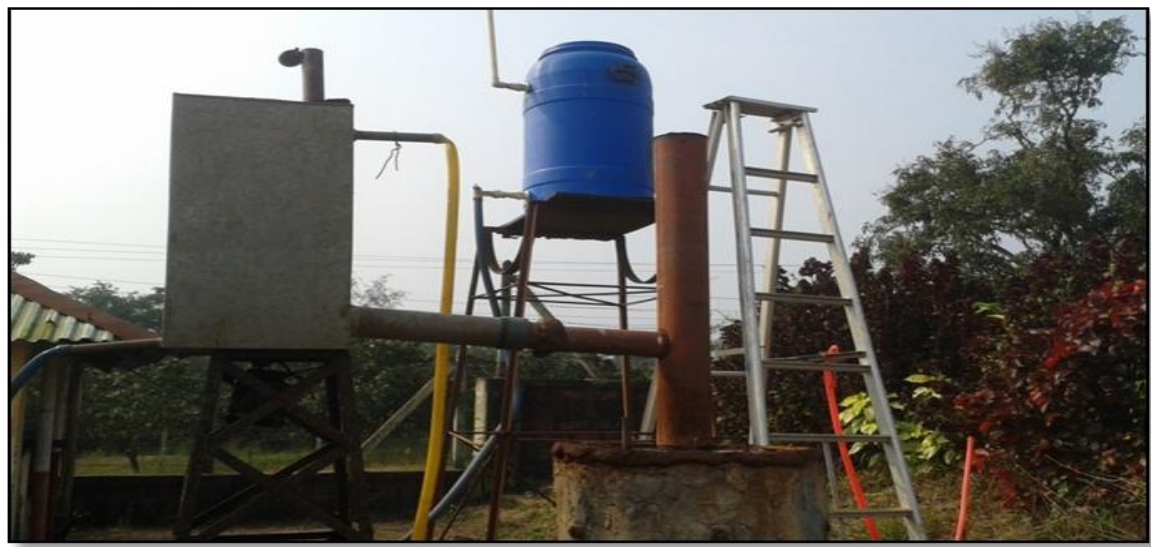

Table.1 Technical specifications of carbonization cum liquefaction unit

\begin{tabular}{l|l|l|l} 
Sr. No. & Particulars & Specifications, mm & Material
\end{tabular}

I.

Carbonization unit

\begin{tabular}{|c|l|l|l|}
\hline 1. & Exit chimney & $950 \times 130 \times 2$ & GI sheet \\
\hline 2. & Top cover & $61 \mathrm{~mm} \phi$ & MS 18 SWG \\
\hline 3. & Carbonization chamber & $900 \times 550 \times 2$ & MS 18 SWG \\
\hline 4. & Inlet air vent & $330 \times 300 \times 2$ & GI Pipe \\
\hline 5. & Exit door & $233 \times 240 \times 2$ & MS 18 SWG \\
\hline
\end{tabular}

II.

\section{Liquefaction unit}

\begin{tabular}{|c|l|l|l|}
\hline 6. & Inner jacket, $\mathrm{mm}$ & $600 \mathrm{~L} \times 300 \mathrm{~W} \times 300 \mathrm{H}$ & GI $18 \mathrm{SWG}$ \\
\hline 7. & Outer jacket, $\mathrm{mm}$ & $660 \mathrm{~L} \times 360 \mathrm{~W} \times 360 \mathrm{H}$ & GI $18 \mathrm{SWG}$ \\
\hline 8. & Inlet water pipe, $\mathrm{mm}$ & $150 \mathrm{~L} \times 25 \phi$ & GI pipe \\
\hline 9. & Outlet water pipe, $\mathrm{mm}$ & $200 \mathrm{~L} \times 25 \phi$ & GI pipe \\
\hline 10. & Inlet flue gas pipe, $\mathrm{mm}$ & $300 \mathrm{~L} \times 100 \phi$ & GI pipe \\
\hline 11. & Outlet flue gas pipe, $\mathrm{mm}$ & $200 \mathrm{~L} \times 40 \phi$ & GI pipe \\
\hline 12. & Outlet of bio-oil pipe, $\mathrm{mm}$ & $30 \mathrm{~L} \times 25 \phi$ & GI pipe \\
\hline
\end{tabular}

Table.2 Characterization of coconut shell and its output

\begin{tabular}{|c|l|c|c|c|}
\hline Sr. No. & \multicolumn{1}{|c|}{ Parameters } & $\begin{array}{c}\text { Coconut shell (Cocus } \\
\text { nucifera) }\end{array}$ & Charcoal & Bio-oil \\
\hline 1. & Moisture content, \% & 12.38 & 6.50 & - \\
\hline 2. & Volatile matter, \% & 63.98 & 12.5 & - \\
\hline 3. & Ash content, \% & 1.84 & 4.5 & - \\
\hline 4.s & Fixed carbon, \% & 21.80 & 76.50 & - \\
\hline 5. & Higher calorific value, $\mathrm{kcal} / \mathrm{kg}$ & 5041 & 6795 & 5320 \\
\hline 6. & Bulk density, $\mathrm{kg} / \mathrm{m}^{3}$ & 486.33 & 618.87 & 1095 \\
\hline 7. & pH & - & - & 5.25 \\
\hline 8. & Viscosity at $28.6^{0} \mathrm{C}, \mathrm{Cs}$ & - & - & 4.02 \\
\hline
\end{tabular}


Table.3 Operating parameters of carbonization cum liquefaction unit

\begin{tabular}{|c|c|c|c|}
\hline $\begin{array}{l}\text { Sr. } \\
\text { No. }\end{array}$ & \multicolumn{2}{|c|}{ Parameters } & $\begin{array}{l}\text { Coconut shell } \\
\text { (Cocus nucifera) }\end{array}$ \\
\hline 1. & \multicolumn{2}{|c|}{ Weight of biomass, $\mathrm{kg}$} & 32.95 \\
\hline 2. & \multicolumn{2}{|c|}{ Size of biomass, $\mathrm{m}$} & $\begin{array}{l}\phi=0.05-0.07 \\
h=0.05-0.08\end{array}$ \\
\hline 3. & \multicolumn{2}{|c|}{ Average wind speed, $\mathrm{m} / \mathrm{s}$} & 2.17 \\
\hline 4. & \multicolumn{2}{|c|}{ Quantity of supplementary fuel, ml } & 160 \\
\hline 5. & \multicolumn{2}{|c|}{ Operating time, hr. } & 7.17 \\
\hline \multirow[t]{3}{*}{6.} & \multirow[t]{3}{*}{ Output } & 1. Charcoal, kg & $10.83(32.86 \%)$ \\
\hline & & 2. Unburnt, kg & $1.64(4.98 \%)$ \\
\hline & & 3. Ash, kg & $0.28(0.86 \%)$ \\
\hline 7. & \multicolumn{2}{|c|}{ Ambient temperature, ${ }^{0} \mathrm{C}$} & 32.63 \\
\hline 8. & \multicolumn{2}{|c|}{ Temperature of flue gas at exit of carbonization, ${ }^{0} \mathrm{C}$} & 225.66 \\
\hline 9. & \multicolumn{2}{|c|}{$\begin{array}{l}\text { Temperature of flue gas at exit carbonization cum liquefaction } \\
\text { unit, }{ }^{0} \mathrm{C}\end{array}$} & 51.08 \\
\hline 10. & \multicolumn{2}{|c|}{ Temperature of inlet cold water, ${ }^{0} \mathrm{C}$} & 33.84 \\
\hline 11. & \multicolumn{2}{|c|}{ Temperature of outlet hot water, ${ }^{0} \mathrm{C}$} & 38.27 \\
\hline 12. & \multicolumn{2}{|c|}{ Output of liquefaction, ml } & 3140 \\
\hline
\end{tabular}

Table.4 Efficiency of carbonization using coconut shell as biomass

\begin{tabular}{|l|l|c|}
\hline Sr. No. & Conversion efficiency & Coconut shell (Cocus nucifera) \\
\hline 1. & Mass conversion efficiency, \% & 42.4 \\
\hline 2. & Volumetric energy ratio & 4.0164 \\
\hline 3. & Energy density ratio & 2.40 \\
\hline
\end{tabular}

Table.5 Energy input and output of carbonization cum liquefaction process

\begin{tabular}{|l|l|l|l|l|l|l|l|}
\hline \multirow{2}{*}{$\begin{array}{l}\text { Sr. Process } \\
\text { No }\end{array}$} & \multicolumn{3}{|c|}{ Input } & \multicolumn{3}{c|}{ Output } \\
\cline { 3 - 9 } & Mass, & $\begin{array}{l}\text { Heat } \\
\text { kalue, } \\
\text { kcal/kg }\end{array}$ & $\begin{array}{l}\text { Energy, } \\
\text { kcal }\end{array}$ & $\begin{array}{l}\text { Mass, } \\
\text { kg }\end{array}$ & $\begin{array}{l}\text { Heat } \\
\text { value, } \\
\text { kcal/kg }\end{array}$ & $\begin{array}{l}\text { Energy, } \\
\text { kcal }\end{array}$ \\
\hline 1. & $\begin{array}{l}\text { Coconut } \\
\text { shell }\end{array}$ & 32.95 & 5041 & 166101 & - & - & - \\
\hline 2. & Charcoal & - & - & - & 10.83 & 6795 & 73589.9 \\
\hline 3. & Unburnt & - & - & - & 1.64 & 5041 & 8267.24 \\
\hline 4. & Bio-oil & - & - & - & 3.14 & 5320 & 16704.8 \\
\hline 5. & Hot water & - & - & - & 273.43 & 1 & 1211.30 \\
\hline 6. & Total & & & 166101 & & & 99773.2 \\
\hline
\end{tabular}


Mass and energy balance of carbonization and liquefaction process

The different efficiencies of carbonization and liquefaction i.e. conversion efficiency, volumetric energy ratio and energy density ratio were determined. The efficiency of carbonization with liquefaction using coconut shell (Cocus nucifera) biomass are summarized in Table 4.

The results revealed that mass conversion efficiency of combined process was 42.4 percent. The volumetric energy ratio was found to be 4.02 . The energy density ratio was found to be 2.40 for coconut shell (Cocus nucifera). It gives both products charcoal as well as bio-oil which have higher calorific value than its raw material. Also the integrated unit releases the flue gases at low temperature $\left(55^{\circ} \mathrm{C}\right)$ as compared to carbonization only $\left(225^{\circ} \mathrm{C}\right)$ in the atmosphere which reduced the effects on environmental condition as well as produces hot water which can be used for domestic purpose.

\section{Energy balance of carbonization cum liquefaction process}

The energy input and output of carbonization cum liquefaction process of selected biomass are shown in following Table 5.

The energy value of the original $32.95 \mathrm{~kg}$ of coconut shell biomass was $166101 \mathrm{kcal}$ which is converted in to various products in the combine unit and produced $10.83 \mathrm{~kg}$ coconut shell charcoal $(73589.9 \mathrm{kcal}), 3.14$ litre biooil $(16704.8 \mathrm{kcal}) 273 \mathrm{ltr}$. Of hot water (1211.3 kcal).

The total output energy of process using coconut shell in carbonization cum liquefaction process was $99773.2 \mathrm{kcal}$ which is $60 \%$ of the original value as compared to $25 \%$ in traditional charcoal kiln alone.
The combine carbonization cum liquefaction study of locally available biomass i.e. coconut shell (Cocus nucifera) fuel showed its higher suitability for charcoal and bio-oil production in terms of mass conversion efficiency, volumetric energy ratio, energy density ratio, storage and handling properties. The combine process of carbonization and simultaneous liquefaction recovered the higher energy than single process of carbonization.

\section{References}

Adam 2009. Improved and more environmentally friendly charcoal production system using low cost retort kiln. Eco-charcoal renewable energy, Vol. 34: 1923-1925.

Anonymous 2009. Food and Agriculture Organization of the United Nations: Economic and Social Department: The Statistical Division.

Anonymous 2011. Department of Indian Agriculture and Cooperation, Ministry of Agriculture.

Ansari 2012. International journal of chem. Tech research, Vol. 1:58-74.

Bahng M. K, Mukarakate and Robinchand D 2009. Energy conversion and management. Vol.51:2330-2339.

Burnette R. 2010. Charcoal Production in 200 litre. Horizontal Drum Kilns, ECHO Asia Notes: 1-12.

Chauhan 2010. Issues of renewable energy technology, Vol.1: 10-15

Chyan 2005. Development of high yield and low cycle time biomass char production system, fuel processing technology, Vol. 87: 487-495.

Demirbas A. 2009. Sustainable Production and Charcoal Briquetting. Energy Sources: Recovery, Utilization and Environmental Effects, Vol. 31 (19): 1694-1699. 
Erakrumen and Agbontalor 2007.AmericanEurasian journal of agriculture and environmental science, Vol. 2: 60-65

Gadakh and Khandekar 2015, "Study of Carbonization and Liquefaction of Biomass", Department of Electrical and Other Energy Sources, CAET, Dapoli.

Julian A. Benzon 1980. The coconut as renewable energy sources. Phillipine Journal of Coconut Studies, Vol (8):252

Klass D 2004. Biomass for renewable energy, Fuel and chemical academic press limited London, Vol. 2:112-114.

Laird D.A and Brown R. C. Amonette J. E. and Lehmann J. 2009. Pyrolysis Platform for Coproducing Bio-oil and Biochar, Biofuels, Bioproduction and Biorefineries Vol. 3: 547-562.

Lindfors 2009. Production of bio-oil from forest residue. VTT Technical Research Centre of Finland P. O. Box 1000, FI02044 VTT: 1-6.

Liu Z. and R. Balasubramanian 2013. A Comparison of Thermal Behaviours of Raw Biomass, Pyrolytic Biochar and their Blends with Lignite. Bio-resource Technology, Vol. 146: 371-378.

Loneza G. Carnobel, Mary Mina P. Odiem, 2013. Powdered coconut shell. International Journal of Advanced
Research in IT and Engineering. Vol. 2| No. 7.

McKenry P. 2001. Biomass Conversion Technologies. Bio resource Technology, Vol.83: 47-54.

Mohod A.G. and N. L. Panwar 2011. Evaluation of Traditional Half Orange type Charcoal Kiln for Carbonization: A Case Study. World Review of Science, Technology and Sustainable Development, Vol. 8 (2/3/4): 196-202.

Radhakrishnan C, Karunaraja N 2015, "Experimental Analysis of Bio-oil from Coconut Shell and Front by Continuous Pyrolysis Process". International Journal of Innovation Research in Science Engineering and Technology. Vol.5: 2319-8753.

Sanke and Reddy 2008. Biomass energy technology transfer, Vol 24 (4): 16-28

Sengar S. H., Mohod A. G., Khandetod Y. P. Studies on metallic kiln for coconut shell, Vol. 1: 8-15.

Shukla P.R. 1997. Biomass Energy in India: Transition from Traditional to Modern. The Social Engineer. Vol. 6:1-19.

Sundaram E G, Nataranjan E, 2009. "Pyrolysis of Coconut Shell": An Experimental Investigation. The Journal of Engineering Research. Vol.6: 233239.

\section{How to cite this article:}

Joshi Priyanka Suhas, Khot Samreen Anwarali, A.G. Mohod and Khandetod, Y.P. 2018. Energy Balance Study of Combined Carbonization and Liquefaction of Coconut Shell. Int.J.Curr.Microbiol.App.Sci. 7(09): 2238-2247. doi: https://doi.org/10.20546/ijcmas.2018.709.277 